\title{
VOTERS’ VAGARIES
}

\section{THE VALUE OF POSITION ON A BALLOT}

\author{
BY ROBERT C. BROOKS \\ Swarthmore College
}

Illustrating by a concrete case some elements which distort the expres-

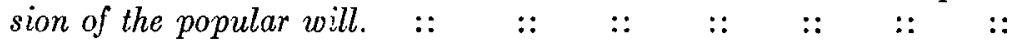

For a short time following every election there is no more favorite form of indoor sport among politicians than the analysis of the returns, with special reference to the vagaries of the voters. The gentlemen who thus amuse themselves are subject to no illusions regarding the intelligence of the electorate. They know that certain quotas of voters will vote for every Irish or German or Polish name on the ballot, and that others will vote against all candidates of foreign extraction. They know that by running a nonentity whose surname happens to be the same as that of some leading candidate they can always split off part of the vote of the latter. And they are familiar with the antics of the occasional joker who zigzags back and forth across the ticket with no apparent motive except to cause additional work and profanity on the part of the long suffering election officials when they come to count his ballot.

Politicians also know to a certitude that the most careful instructions regarding voting will fall short of complete execution owing to the invincible ignorance or neglect of many of their followers. Sample ballots fully supplied with cross marks in the right places are left at home, or, if carried to the polls make too severe a demand upon the gray matter of the voter, although all that the latter has to do is to duplicate these cross marks upon an identically similar official ballot. Politicians are further aware that failure to place the name of the candidate upon the printed ballot is an almost impossible handicap, and that no amount of exhortation to "write in" that name will be more than partially effective. "Stickers" may help somewhat, but many voters throw them away, while others attach them everywhere on the ballot except the one place where they will count as intended. Finally there is general agreement among politicians as to the value of a good position on the ballot. Election returns are usually so complicated, however, that it is difficult to ascertain with any degree of exactness the weight of this factor.

\section{UNDER TEST CONDITIONS}

A primary election held in Pennsylvania, May 18, 1920, was so simple, at least so far as the Democratic ticket was concerned, that it affords unusual opportunity to investigate the last named point. By way of general description it may be said that the Democratic voters were divided on this occasion into two wings, one following the leadership of AttorneyGeneral Palmer, the other that of Judge Eugene C. Bonniwell. It can scarcely be maintained that many issues were involved in the fight except as to the local records of the two lead- 
ers and their followings, and into that long story it is not necessary to go here. In addition to these differences the Bonniwell faction sought to make the most of the anti-prohibition sentiment. Both wings professed devotion to the Wilson administration, although, of course, Mr. Palmer's membership in the official family of the president placed his faction in a much more advantageous position to press this point.

In Pennsylvania primaries only enrolled voters may participate, that is, only those who in addition to other qualifications have formally declared in writing their adhesion to the party the primary ballot of which they desire to vote. ${ }^{1}$ The electorate on this occasion, therefore, was made up of party regulars, who might be expected to take more interest in politics than the large mass of voters who are too independent (or too much afraid of social or business pressure) to enroll in any party. Every one of these "regulars" received campaign literature from the two factions, including either marked sample ballots or lists of candidates for whom he was asked to vote. The party press also devoted rather more than the usual amount of space to the fight between the two factions.

Thus prepared, such an electorate might be expected to vote "straight" to a greater degree than the wider electorate at a final election. Whether or not its intelligence in handling the ballot is greater than that of the general electorate is questionable. On the whole, however, the primary electorate of May 18, 1920, may be assumed to have been quite normal in the vagaries it displayed,--if such a phrase be allowable.

\footnotetext{
${ }^{I}$ Except for judicial offices for which a nonpartisan primary ballot may be used by all voters whether enrolled as party members or not.
}

The most hotly contested fight in the whole primary election raged about the office of national committeeman. It involved the same candidates, Mr. Bonniwell on the one side and Mr. Guffey on the other, who had been pitted against each other for the Democratic gubernatorial nomination two years earlier. Considerable personal bitterness had remained from this earlier struggle. Moreover, as a party office, the decision of the primary of May 20 was final, no subsequent ballot being necessary as in the case of nominations for state and national offices. In a minority party, such as the Democracy in Pennsylvania, it is, of course, quite commonplace to find more effort bestowed on securing party office than in securing nomination for actual public office, since the latter is usually an empty honor to which is attached the hard work of campaigning a second time.

In round numbers one hundred and twenty-five thousand votes were cast in the Democratic primary, of which Mr. Bonniwell received 45 per cent, and his opponent, Mr. Guffey, 55 per cent. The same percentages were very closely approximated in the average vote cast by the two factions for delegates at large to the Democratic National Convention and for representatives in congress at large. It seems fairly clear, therefore, that of the voters who presented themselves at this primary, sixty-nine thousand were followers of the Palmer faction, and fifty-six thousand of the Bonniwell faction.

Using this as the best obtainable basis for further comparisons, we may now consider some of the results of the struggle between the two factions over the twelve delegates at large to the Democratic National Convention. Each faction nominated a complete ticket for these offices, so that the 
voter was confronted with a list of twenty-four names, alphabetically arranged, and accompanied by no further information except the address and county of each candidate, and his promise or refusal to promise "to support popular choice of party in the state for president."' 1 From this list of twenty-four names the voter was instructed to "vote for twelve."

It is to be presumed that each of the twenty-four candidates possessed some local following, but for very few of them could more than this be claimed. The writer has followed Pennsylvania politics, state and local, with close attention for twelve years, and in addition was factional leader of a congressional district in this primary, but he must confess that of this list of twenty-four names he knew but two personally and two others vaguely by reputation. With the overwhelming majority of other voters he would have been unable to vote intelligently (that is, in this case, for men supporting his choice for the presidency and his convictions on national issues) for delegates at large to the national convention without the aid of the marked sample ballot printed by his faction.

That such sample ballots were largely used, the results clearly show; that, on the other hand, their effectiveness was diminished by the position of names on the ballot appears with equal clearness. It was, of course, by no means accidental that the first six names on the ballot, all of them belonging to the Bonniwell faction, begin with the letter $A$. The following seven names begin with the letter $B$, and four C's come next. Of the entire twenty-four, seven only have names beginning farther down in the alpha-

${ }^{1}$ Of the Palmer list all but one promised to do so; of the Bonniwell list all but one refused to make this promise. bet than $C$, and of these seven it was the misfortune of the Palmer faction to have named five. ${ }^{2}$

\section{THE ALPHABET IN POLITICS}

The first candidate on the list received by far the largest vote $(55,063)$ of any of the Bonniwell nominees for national delegate. It is worth noting, however, that he did not poll as large a vote by 1,505 as $\mathrm{Mr}$. Bonniwell himself did for national committeeman, although the list of twenty-four candidates for delegates occupied a more prominent place on the ballot. ${ }^{3}$ Similarly the high man of the Palmer list for delegates started out with 1,058 votes less than were cast for $\mathrm{Mr}$. Guffey as national committeeman. In other words, out of a total vote of 125,000 , rather more than 2,500 , or 2 per cent, who voted readily enough as between the names of two candidates, refused even to begin the ardu-

${ }^{2}$ In the following table, showing the vote for each of the twenty-four candidates for national delegate at large, names of the Palmer candidates are italicized:

$\begin{array}{llll}\text { Allen, } & \mathbf{5 5 , 0 6 3} & \text { Brodbeck, } & \mathbf{5 4 , 9 8 8} \\ \text { Altmiller, } & \mathbf{5 0 , 4 0 3} & \text { Casey, } & \mathbf{5 9 , 9 5 1} \\ \text { Amig, } & \mathbf{4 7 , 6 9 8} & \text { Connelly, } & \mathbf{4 2 , 1 4 4} \\ \text { Ammerman, } & \mathbf{4 6 , 9 5 0} & \text { Core, } & \mathbf{5 0 , 4 0 3} \\ \text { Ancona, } & \mathbf{4 8 , 3 1 2} & \text { Crawford, } & 37,424 \\ \text { Andre, } & \mathbf{4 6 , 9 0 7} & \text { Diffenderfer, } & 35,068 \\ \text { Barnum, } & \mathbf{6 7 , 3 4 6} & \text { Dodds, } & \mathbf{5 1 , 2 1 6} \\ \text { Bigelow, } & 67,632 & \text { Donnelly, } & 53,069 \\ \text { Blakeslee, } & \mathbf{6 4 , 0 9 8} & \text { Fagan, } & 51,830 \\ \text { Bonner, } & 48,739 & \text { Grimm, } & 50,068 \\ \text { Bradigan, } & 46,905 & \text { Holstein, } & 32,609 \\ \text { Bright, } & 62,661 & \text { Light, } & 49,078\end{array}$

The vote of Mr. Bonniwell for national committeeman was 56,568; of Mr. Guffey, 68,690. For these figures the writer desires to express his obligation to Mr. Warren VanDyke of Harrisburg, Pa.

3 They were at the top of the second column, directly over the square containing the names of the two candidates for the national committee. 
ous task of picking twelve out of twenty-four.

A much larger number of those who started valiantly upon the latter task fell by the wayside. Thus taking the Bonniwell list of twelve candidates the vote declines steadily, with but two irregularities, from 55,063 for Number One to 32,609 for Number 'Twelve. The descent is more irregular in the Palmer list, but it is none the less marked, its extremes ranging from 67,632 cast for the second on that list to only 49,078 cast for the twelfth. Summing up the extremes of both factions we may say that of one hundred and twenty-three thousand men who started out to vote for twelve candidates out of twenty-four, only eighty-two thousand, or two-thirds, persevered to the end. Having reference not to the extremes, but to the whole mass of votes actually cast for delegates at large, the matter may be stated in another way. The one hundred and twenty-five thousand men, who expressed themselves fully where the question was one of choice between two candidates, developed the voting strength of only one hundred and two thousand men where the question was that of choosing twelve names out of twenty-four. ${ }^{1}$ And of these one hundred and two thousand, only ninety-six thousand voted straight, which in this case amounted to the same thing as voting intelligently.

The average vote of the twelve Bonniwell candidates was about fortyfive thousand. ${ }^{2}$ Some measure of the importance of having first place on the ballot may be gained from the fact

1 The total number of votes cast for the twenty-four was $1,220,587$. As each voter was entitled to twelve votes, this is equivalent to the voting strength of 10I,715 men only.

2 Exactly 44,851. that the Bonniwell candidate, who enjoyed that advantage, ran ahead of this average by 10,212 votes, or 22.8 per cent. The second candidate, also a Bonniwell man, exceeded the average by 5,552 , or 12.3 per cent. At the other end of the scale, the last Bonniwell candidate, who had twenty-third place on the ballot, fell behind the average by 12,242 votes, or 27.3 per cent.

The same tendency appears in the case of the Palmer candidates, but not so markedly, for the first candidate of this slate came seventh in alphabetical order on the ballot. Nevertheless, he ran 10,482 votes, or 18.4 per cent, ahead of the average vote of his colleagues. The last Palmer candidate, whose place was twenty-fourth on the ballot, fell 7,786 votes, or 13.7 per cent, behind the average for this slate.

A large number of voters, confronted by the injunction to "vote for twelve" of the twenty-four candidates, solved the problem by placing a cross to the right of the first twelve names on the ballot, utterly regardless of their affiliation with one or the other faction. As a result of this tendency the first twelve candidates on the ballot received 66,450 votes in excess of their total average, ${ }^{3}$ while the last twelve fell 66,443 below their total average. ${ }^{4}$ To put the matter in another way, about five thousand five hundred men, or 4.4 per cent of the total participating in the election, cast all their twelve ballots for the first twelve names on the list, regardless of the fact that eight of them were for McAdoo for president. and four for Palmer.

\footnotetext{
3 As eight of these were for Bonniwell and four for Palmer, this total average would be $(8 \times$ $44,851)+(4 \times 56,864)$, or 586,624 votes.

4 In this case the proportion of Bonniwell and Palmer men is reversed, so that the total average stands $(4 \times 44,851)+(8 \times 56,864)$, or 634,316 .
} 
WRITING-IN A NAME.

The most prominent place on the ballot of May 18, - at the top of the first column devoted to partisan candidates,--was given to the expression of the presidential preferences of the voters. However, the only name printed in this square was that of $\mathrm{Mr}$. Palmer, as his followers alone had taken the trouble to circulate nominating petitions in his behalf. In the latter stages of the campaign the Bonniwell faction decided to support Mr. McAdoo. Although they advertised this decision vigorously and circularized all the Democratic electors of the state in his favor, they were at a disadvantage, both because of their late start and because their adherents were obliged to write in the name of their presidential preference.

As a result $\mathrm{Mr}$. Palmer received 76,254 votes, or seven thousand five hundred more than were cast for any other statewide candidate on the Democratic primary ticket. Nevertheless, 21,439 electors voted for $\mathrm{Mr}$. McAdoo, certainly a large number considering the circumstances. In attempting to estimate how great was his loss, largely due to the fact that those who favored him had to write in his name, it should be recalled that in voting for delegates at large to the Democratic National Convention, all of whose names were printed on the ballot, 44 per cent of the electors supported candidates who unquestionably would have voted for Mr. McAdoo at San Francisco. On this basis it seems fair to assume that about fifty-five thousand voters would have expressed a preference for Mr. McAdoo if his name had been printed on the ballot. As a matter of fact only 21,439 , or 38.9 per cent of the above number, did so. Of the remainder one-half, or twenty-seven thousand five hundred, did not vote at all, and at least six thousand, or nearly 11 per cent, placed a cross to the right of Mr. Palmer's name. Of course these six thousand contradicted their own votes for national delegates. It is conceivable that some portion of them were influenced by state pride or by personal admiration for Mr. Palmer. Others, however,-how many it is impossible to say,--simply "obeyed that impulse," moved by the curt injunction to "vote for one," and the fact that only one name was printed beneath it.

As a result of the various tendencies noted above, the Bonniwell faction, in spite of its substantial inferiority, was successful in breaking the Palmer slate in two places. They elected two of the delegates at large to the national convention, the successful candidates in this instance being the two at the top of the list, while the two Palmer men who were defeated were the last two names on that slate. By the same tactics the Bonniwell faction also succeeded in naming one of the four nominees for representative in congress at large. In one other case, that of the nomination for United States senator, the Palmer slate was broken, but here the result seems to have been due to the war record and the personal popularity of the successful candidate.

\section{CONCLUSION}

Of course voters' vagaries, such as are discussed above, have long been observed. All that the present study can claim to accomplish is that it has given them quantitative analysis in the comparatively simple case of a single election. To this extent it establishes the degree of invisibility which Short Ballot writers have pointed out as a consequence of our long ballots, and confirms the need of the reform they advocate. 